PAWE $Ł$ WAWRYSZUK

Instytut Historii i Stosunków Międzynarodowych UKW

\title{
Slobodan Milošević - demon czy zbawca narodu serbskiego?
}

\section{Wprowadzenie}

Clowa „Nikt nie ma prawa was bić!” wypowiedziane przez Slobodana Miloševicia w kwietniu 1987 roku w płomiennym wystąpieniu na Kosowym Polu, otworzyły politykowi drogę do wielkiej polityki. Koniec lat osiemdziesiątych XX wieku upływał pod znakiem narastającej frustracji wśród Serbów, wzmaganej ogromnymi problemami ekonomicznymi Jugosławii, objawiającymi się spadkiem produkcji przemysłowej, a w efekcie recesją, wzrostem bezrobocia i wysoką inflacją (rzędu 170\%) $)^{1}$. Zapoczątkowany przez Titę proces decentralizacji federacji jugosłowiańskiej po jego śmierci zaczął prowadzić do wzrostu nastrojów separatystycznych. W przekonaniu wielu Serbów to właśnie oni byli narodem pokrzywdzonym - i to nie tylko na poziomie republik związkowych, lecz także w samej Serbii, gdzie okręgi autonomiczne Kosowa i Wojwodiny stały się niemal całkowicie niezależne od Belgradu, a ludność serbska była dyskryminowana ${ }^{2}$. Milošević doskonale zdawał sobie z tego sprawę, widząc w tym swoją szansę osiągnięcia większych wpływów w partii.

Do połowy lat osiemdziesiątych Slobodan Milošević nie był wyróżniającym się politykiem. Skończył prawo na uniwersytecie w Belgradzie w 1964

M. J. Zacharias, Komunizm, federacja, nacjonalizmy. System władzy w Jugosławii 1943-1991. Powstanie - przekształcenia - rozkład, Warszawa 2004, s. 430.

Tamże, s. 423. 
roku, do partii wstępując pięć lat wcześniej. Przez następne dwadzieścia lat pełnił funkcje gospodarcze, m.in. doradcy ekonomicznego burmistrza Belgradu, szefa spółki ${ }^{3}$ Technogas oraz prezesa największego banku Jugosławii Beogradska Banka ${ }^{4}$. W karierze politycznej opierał się głównie na swoim „przyjacielu” ${ }^{5}$ i współpracowniku Ivanie Stamboliciu, który był niejako jego promotorem, aktywnie wspierającym w wyborach na ważne partyjne funkcje. Dla polityków jugosłowiańskich „nowego pokolenia”, co miało niemały wpływ na pogłębianie różnic w państwie, celem były przede wszystkim stanowiska partyjne oraz władza w republikach. Najpierw w 1984 roku Milošević został wybrany szefem belgradzkich komunistów, zaś dwa lata później przewodniczącym Związku Komunistów Serbii.

Jak oceniać ponad dekadę niezachwianych rządów Miloševicia? Co przyniosły Serbii, Serbom oraz całym Bałkanom? Postać tego polityka jest bardzo wieloznaczna, przy czym wiele aspektów jego działalności obrosło w mity. Często, w szczególności na Zachodzie, przypisuje mu się wyłączną winę za krwawy rozpad Jugosławii, czystki etniczne w Bośni i Hercegowinie czy Kosowie. Niejednoznaczna wydaje się kwestia, w jaki sposób rządy Miloševicia wpłynęły na dzisiejszą Serbię, w której partia nacjonalistyczna nadal jest jedną z głównych sił politycznych. Wreszcie nurtująca jest kwestia, czy Serbii uda się rozliczyć z przeszłością i zbudować nowoczesną państwowość w nowej rzeczywistości.

„General manager of Technogas” - jednak dokładne tłumaczenie na język polski tej funkcji wydaje się mało trafione, szczególnie gdy ma się na uwadze funkcjonowanie firmy w realiach gospodarki komunistycznej.

Slobodan Milosevic's Biography, http://www.slobodan-milosevic.org/biography.htm [dostęp: 22.02.2010]. Z bankiem tym, a wedle Riccarda Orizia - także z Miloševiciem, związana jest pewna afera. Otóż w 1994 roku były agent serbskiej tajnej policji Nenad Djordjević, prywatnie przyjaciel wodza, odkupił od państwowego przedsiębiorstwa (niewymienionego z nazwy) willę w Belgradzie za ok. dwa mln dolarów, pożyczonych właśnie od tego banku. Po roku odsprzedał ją partii JUL (Jugoslovenska Levica), założonej przez Mirjanę Marković, żonę Miloševicia, za połowę ceny, ale z deklaracją przejęcia jego zobowiązań przez partię. Djordjević zarobił milion dolarów, natomiast Beobank został z nieściągalnym długiem. Dwa mln dolarów, które trafiły do przedsiębiorstwa, przepadły bez śladu. Brak jest jednoznacznych dowodów, by Milošević brał udział w tym oszustwie, natomiast można stwierdzić z całą stanowczością, iż sprawa ta jest co najmniej kontrowersyjna. R. Orizio, Diabeł na emeryturze. Rozmowy z siedmioma dyktatorami, Poznań 2004, s. 173-175.

Były zwierzchnik Miloševicia zaginął 25 sierpnia 2000 roku. Jego ciało odnaleziono trzy lata później. Zdaniem prawnika rodziny Stambolić, mimo utraty stanowisk partyjnych, zachował swoje kontakty „od Macedonii, przez Czarnogórę po Słowenię”, co obok popularności tego polityka mogło być głównym motywem zbrodni. W wyniku procesu wydanie rozkazu zabójstwa przypisano Miloševiciowi, 6 wykonawców skazano na kary od 15 do 40 lat więzienia. Główni oskarżeni nie byli obecni na sali rozpraw: Milošević przebywał już w więzieniu w Hadze, zaś Rade Marković, szef tajnej policji, w tamtym czasie jeszcze się ukrywał, por.: G. Partos, Analisys: Stambolić murder trial, http://news.bbc.co.uk/ 2/hi/europe/ 3511823.stm [dostęp: 15.03.3010]. 


\section{Droga do władzy - czynniki decydujące}

"Slobo" w trakcie debaty o zmianach ustrojowych Serbii zyskiwał na popularności. Organizował wiece, w trakcie których w sposób emocjonalny odnosił się do serbskiego dziedzictwa w Kosowie. Skutecznie wzmagał obraz narodu oblężonego ze wszystkich stron, zagrożonego zniszczeniem. W podobnym tonie rzeczywistość opisali naukowcy z Serbskiej Akademii Nauk I Sztuk w wystosowanym w 1986 roku Memorandum. Publikacja ta składała się z dwóch części: pierwsza przedstawiała ówczesną sytuację w Jugosławii. Nie wykluczano możliwości rozpadu federacji, za co winą obarczono system wprowadzony przez konstytucję z 1974 roku. W odróżnieniu od rzeczowej i stonowanej części pierwszej dokumentu, część druga - traktująca o pozycji Serbów w państwie - była mniej obiektywna. Podkreślono upośledzenie Serbii $\mathrm{w}$ federacji, utratę kontroli nad okręgami (co było zgodne z prawdą) I dyskryminowanie ludności serbskiej zamieszkującej poza granicami Serbii. Jednym z głównych postulatów akademików był powrót centralizacji państwa i odejścia od obowiązującej konstytucji. Nowa Jugosławia miała być oparta na idei samostanowienia narodów, a nie suwerenności republik, co dawałoby Serbom mieszkającym w innych republikach większe prawa. Członek Akademii, Matija Bećković, tak określał pozycję mniejszości serbskich zamieszkałych w innych republikach: „Serbowie, zwłaszcza w Chorwacji, są resztką zamordowanego narodu. Strach przed nieistnieniem rozpala nienawiść do innych, a nienawiść wyzwala siłę". Tę siłę zaczął uosabiać Slobodan Milošević. Stał się w opinii wielu jedynym człowiekiem mogącym stawić czoła wszystkim zagrożeniom serbskiej państwowości. Dnia 28 czerwca 1989 roku, w sześćsetną rocznicę bitwy na Kosowym Polu, przemawiał do tłumów słowami: „Sześć wieków po bitwie kosowskiej ponownie toczymy bitwy. Nie są one zbrojne, ale i takie nie są wykluczone" . Takie hasła trafiały na bardzo podatny grunt. Narastająca frustracja, kryzys ekonomiczny, postępująca dezintegracja, fala niepokojów społecznych, widmo rozpadu Jugosławii z jednej strony - z drugiej pewny siebie polityk, świadom zagrożeń wiszących nad Serbią, głoszący konieczność prowadzenia polityki zgodnie z „serbską racją stanu". Milošević zyskał szerokie poparcie społeczeństwa, także części twórców czy autorytetów. W roku 1989 został przewodniczącym Prezydium Serbii na fali haseł odbudowy serbskiej dumy narodowej.

Cyt. za: N. Popov, Serbski dramat. Od faszystowskiego populizmu do Miloševicia, Warszawa 1994, s. 40 .

M. Rekść, Niewola mitu, [w]: Źródła nienawiści. Konflikty etniczne w krajach postkomunistycznych, red. K. Janicki, Warszawa-Kraków 2009, s. 42. 
Wykorzystując rosnącą popularność w społeczeństwie, Milošević zaczął realizować swój cel: budowanie niezachwianej władzy nie tylko w Serbii właściwej, ale także w okręgach autonomicznych i Czarnogórze. Świetnym pretekstem do spacyfikowania niezależnych central partyjnych w Wojwodinie, Czarnogórze i Kosowie okazało się hasło „rewolucji antybiurokratycznej”. Polegała ona na organizowaniu przez osoby pośrednio lub bezpośrednio związane z Miloševiciem mityngów przed siedzibami partyjnymi. Demonstranci przedstawiali skostniałą strukturę partii, niezdolną do walki z narastającymi problemami ekonomicznymi, żądali zmian personalnych. W mityngach brały udział niekiedy dziesiątki tysięcy obywateli, bardzo często szczerze niezadowolonych z sytuacji panującej w republice ${ }^{8}$. Pod taką presją wymienione zostało kierownictwo partyjne w Wojwodinie, Czarnogórze oraz Kosowie. Był to fakt o tyle istotny, iż oba okręgi autonomiczne zgodnie z konstytucją z 1974 roku - miały po jednym głosie w Prezydium SFRJ, podobnie jak Serbia i Czarnogóra. W sumie Milošević mógł liczyć na cztery głosy - tyle samo, ile pozostałe republiki, co powodowało impas decyzyjny na szczeblu federacji. Wykorzystanie niezadowolenia grup społecznych w walce o wpływy partyjne, jak to miało miejsce w Jugosławii, nie było częstym zjawiskiem w państwach bloku komunistycznego. Pewne podobieństwo, ale w o wiele większej skali, wykazywała rewolucja kulturalna w Chinach ${ }^{9}$.

Milošević zaczął się jawić jako jedyna osoba mogąca wyprowadzić naród z kryzysu. Starał się stworzyć wizję, w której wszyscy Serbowie muszą połączyć swe wysiłki na rzecz nie tylko odbudowania gospodarki czy kultury, będących w opłakanym stanie, lecz wręcz przetrwania jako naród. Takiego „oczyszczenia” mógł dokonać jedynie przywódca namaszczony przez lud, który spełniał historyczną posługę wobec swych współbraci, który musiał przeprowadzić Serbię przez okres niepokojów. Jak twierdzi Ivan Čolović, dla Miloševicia najwyższe stanowiska państwowe czy pełnia władzy były tylko narzędziem do osiągnięcia celów narodowych. Był jedynie wykonawcą woli narodu. Podobnie sława i wszystkie zasługi nie były dziełem wodza, lecz losu - okazały się nieuniknione. Wódz jedynie skromnie i z pokorą przyjął rolę, jaką zaoferował mu suweren, wykonywał jedynie jego wolę ${ }^{10}$.

W systemie tworzonym przez Miloševicia bardzo istotnym aspektem było istnienie wroga - nie tylko zewnętrznego, czyhającego na dogodną sposobność do ataku, ale także wewnętrznego, który na usługach wroga spełnia funkcję piątej kolumny. Serbski minister gospodarki Slobodan Tomović

Por.: N. Popov, Serbski dramat, s. 55.

M. J. Zacharias, Komunizm, federacja, nacjonalizmy, s. 448-449.

I. Čolović, Bałkany - terror kultury, Wołowiec 2007, s. 51-53. 
określał zdrajców mianem „NATO-janczarów”. Jak tłumaczył, Turcy uprowadzali dzieci, by „uczyć je nienawiści do ojczyzny, a dziś nasi janczarzy wyjeżdżają w świat po pieniądze i za pieniądze uczą się tam, jak zdradzać swój kraj i swój naród"11. Podobne przyczyny wybuchu wojny w Jugosławii wskazywali respondenci Danko Šipka, reprezentujący „postawę nacjonalistyczną”. Ich zdaniem wojna była wypadkową separatystycznych dążeń Chorwatów, Słoweńców i muzułmanów oraz międzynarodowego spisku mającego na celu zniszczenie Serbii ${ }^{12}$. Apoteoza narodu, od którego pochodziła władza przywódcy, miała służyć jeszcze jednemu celowi - rozmyciu odpowiedzialności za ewentualne ofiary, niepowodzenia.

Sojusznikami Miloševicia zostało wielu artystów, poetów, którzy własnym autorytetem wspierali reżim ${ }^{13}$. Apoteozowano język serbski jako „ostoję bytu narodowego”. Zgodnie z kreowanym obrazem rzeczywistości naród mógł zostać podbity, jego bogactwa i ziemie zagrabione, ale poprzez kultywowanie języka przetrwa duch narodu i pozwoli mu się odrodzić w przyszłości w sprzyjających okolicznościach jeszcze silniejszym. Filolog Miloš Kovačević twierdzi, iż „narody żyjące na jednym terytorium z Serbami i obok Serbów [język] chętnie rabowały. Żaden Serb nie sprzedał swego języka. Odbierali go przemocą silniejsi od nas, a oni wiedzieli, że jeśli zdobędą język, zdobędą też naród"14.

Obrona języka serbskiego nie była jedynym polem, na którym twórcy włączyli się w budowanie nacjonalizmu serbskiego. Równie istotnym, a być może ważniejszym, była szeroko rozumiana kultura. Dominowało stanowisko, iż jedynie kultura serbska jest tą pradawną, czystą, na bazie której inne narody regionu zbudowały swoją tożsamość. Przez to poziom rozwoju kultury sąsiadów musiał być niższy, nie jest niepowtarzalny itp. Warto wspomnieć, że prócz kultury, nieograniczonej ściśle do granic państwowych, wyróżniano tzw. serbską przestrzeń duchową, związaną z najistotniejszymi wydarzeniami w historii Serbii (narodu serbskiego). Jak twierdzi serbski historyk Milorad Ekmečić, „Serbska przestrzeń duchowa [...] ma także historyczną głębię. Gdzie żył naród serbski, tam jest nasza duchowa przestrzeń i zawsze elementem naszego rozumienia i racjonalnej wiedzy będzie świado-

Tamże, s. 53-54.

D. Šipka, Demokracja a interes narodowy w ujmowaniu sytuacji politycznej: przykład wojny $w$ dawnej Jugostawii, Poznań 2002, s. 53-54. Antoni Giza z kolei jako jedną z najważniejszych przyczyn rozkładu Jugosławii wskazywał zmiany demograficzne w federacji na niekorzyść Serbów, por. A. Giza, Narodziny i rozpad Jugosławii, Szczecin 1994, s. 149.

13 M. Tabin, Kosowskie państwo podziemne: nadzieje i dylematy, [w]: Trudne sasiedztwa. Z socjologii konfliktów narodowościowych, red. A. Jasińska-Kania, Warszawa 2001, s. 86-87.

Tamże, s. 42. 
mość, gdzie byliśmy i kim byliśmy"15 - więc także poza granicami Serbii: $\mathrm{w}$ Bośni i Hercegowinie, części Chorwacji, Kosowie (zależnie od punktu widzenia, jaki badacz przyjmie). Plany przywrócenia właściwej pozycji Serbii przez Miloševicia (bądź konieczności bronienia serbskiej przestrzeni duchowej) były zbieżne ze środowiskiem Serbskiej Akademii Nauk i Sztuk. Także i dlatego polityka tego oklaskiwały tysiące ludzi, gdy w płomiennych przemówieniach zapowiadał: ,Jest to proces [solidaryzowania się z Serbami z Kosowa], którego nie zahamuje już żadna siła. Bitwę o Kosowo wygramy bez względu na przeszkody, które nam stawiają w kraju i poza nim. [...] Do tego boju o Kosowo ruszy cały naród, wszyscy obywatele, bez względu na narodowość i profesję. A nie zdarzyła się na świecie bitwa, którą by naród przegrał. Nikt nie powinien być zdziwiony, że cała Serbia stanęła tego lata na nogi z powodu Kosowa. To przecież historyczne i kulturalne centrum, to punkt centralny jej narodowej pamięci" ${ }^{16}$.

Milošević otrzymał także wsparcie Cerkwi prawosławnej, która pod koniec lat osiemdziesiątych zyskiwała coraz większe możliwości swobodnego działania. Metropolita Amfilohije Radović uważał Serbów za ostatni bastion świętości, obrońców prawdziwie prawosławnych wartości. W jego opinii największym zagrożeniem serbskiego sacrum był zdemoralizowany (rzymskokatolicki i protestancki) Zachód oraz ekspansywny świat islamu. Nie bez przyczyny w gronie największych wrogów integralności terytorialnej Jugosławii wymieniano obok Austrii, Niemiec i Włoch - Stolicę Apostolską. $\mathrm{W}$ walce z tymi zagrożeniami, jak mówil, naród musiał być gotowy do ponoszenia ofiar, gdyż śmierć jest warunkiem koniecznym zmartwychwstania. Konieczna jest także mobilizacja, wykrzesanie wszystkich sił, gdyż wróg jest silny. Wszystko to akcentował Milošević. Co więcej, dawał gwarancję, że pod jego przewodnictwem naród tę walkę wygra ${ }^{17}$. Stąd na wiece nowego wodza przychodziły tłumy wiernych.

Przywódca Serbii bardzo często dostosowywał swoją retorykę do sytuacji i adresata słów. Tak czynił szczególnie w stosunku do dowództwa Jugosłowiańskiej Armii Ludowej. Armia z wielkim niepokojem patrzyła na postępującą dezintegrację państwa jugosłowiańskiego. Główną tego przyczyną była jej ,jugosłowiańskość". Niemal cały korpus oficerski (mimo iż zdominowany przez Serbów) swą uprzywilejowaną pozycję zawdzięczał właśnie Jugosławii. Dowództwu obcy był republikański punkt widzenia prezentowany przez polityków, aspiracje poszczególnych republik były nie do zaakcep-

Cyt. za: tamże, s. 64.

S. Milošević, Czas rozstrzygnięć, Warszawa 1990, s. 227-228.

Ch. Mylonas, Serbian orthodox fundamentals: the quest for an eternal identity, Budapest-New York, 2003, s. 125-126. 
towania. Milošević zaś regularnie podkreślał swoje przywiązanie do utrzymania federacyjnego charakteru Jugosławii. W obliczu zgody Miloševicia na secesję Słowenii i Chorwacji (bez Krajiny) okazało się, iż armia jugosłowiańska zyskała nowe oblicze - obrończyni serbskiej koncepcji budowania nowej Jugosławii ${ }^{18}$.

\section{Milošević winny rozpadu Jugosławii?}

Nebojša Popov uważa, że: „Reżim Miloševicia przyczynił się do przerwania więzów na płaszczyźnie Jugosłowiańskiej [wielka litera!], jednocześnie umocnił dążenia innych republik do secesji - i pozwolił im zrzucić całą odpowiedzialność za rozpad Jugosławii na Serbię i naród serbski”" ${ }^{19}$. Niezaprzeczalny jest fakt, iż koniec lat osiemdziesiątych i początek dziewięćdziesiątych w Serbii upłynął pod znakiem rosnących nacjonalizmów, w którym dominowały ksenofobia, wszechobecny wróg zarówno wewnętrzny, jak I zewnętrzny, elementy kultu jednostki czy idea budowy „Wielkiej Serbii” kosztem nawet milionów ofiar, jak mówił do kilku tysięcy zwolenników Marko Jović podczas populistycznego wiecu przed budynkiem parlamentu Jugosławii $^{20}$. Nacjonalizm serbski ${ }^{21}$, umiejętnie podsycany przez Miloševicia i innych, stał się narzędziem do przejęcia przez niego pełni władzy w republice.

Konflikty między poszczególnymi republikami - a w szczególności pomiędzy Serbią a Chorwacją i Słowenią - miały swoje korzenie w ustroju państwa. Po decentralizującej państwo reformie sfinalizowanej uchwaleniem konstytucji SFRJ z 1974 roku mogło ono funkcjonować jedynie w oparciu o niezachwiany autorytet przywódcy - w tym przypadku Josipa Broza-Tity. To on był w stanie hamować ambicje republikańskich polityków. Po jego

18 I. Rycerska, Rozpad Jugostawii. Przyczyny i przebieg, Kielce 2003, s. 75-76.

19 N. Popov, Serbski dramat, s. 57.

20 Tamże, s. 64-65. O konieczności prowadzenia wojny i obrony wartości jedynie słusznych, wręcz zagrożeniu istnienia „człowieka” w razie klęski Serbii pisze Čedomir Popov, por. I. Čolović, Bałkany - terror kultury, s. 112-113.

${ }^{21}$ Ale nie tylko serbski. Elementów nacjonalizmu można doszukać się także u Chorwatów (jak nazwać gloryfikowanie akcji „Burza”, w wyniku której złamany został opór Serbów w Krajinie? - zwycięzcy ogłaszali „powrót prawdziwej kultury na tereny, które przez Serbów zostały zamienione w chlew"), Słoweńców (traktujących serbską kulturę z pogardą), czy nawet Macedończyków. Tamże, s. 12-14. Potomkowie Albańczyków z Kosowa z kolei jako pierwsi przybyli na tereny przez nich zamieszkałe. Wykazują swe związki z pradawnym ludem Ilirów. Nawet język albański, powiadają, wywodzi się od tego ludu. Co więcej, w ciągu kilku dekad stali się odrębnym narodem - Kosowarami. A. Balcer, Rola Kosowa jako centrum aktywności politycznej albańskiego ruchu narodowego i proces budowy odrębnej kosowskiej tożsamości państwowej, [w]: Albanistyka polska, red. I. Sawicka, Toruń 2007, s. 136 i n. Jak się zatem wydaje, nacjonalizm wśród narodów Jugosławii nie był wcale zjawiskiem wyjątkowym. 
śmierci partykularne interesy narodowe, które istniały także wcześniej, ale znajdowały się pod kontrolą, zaczęły brać górę. Rozmywało się natomiast poczucie wspólnoty, odpowiedzialności za federację, gwarantowane osobą przywódcy. Zarówno Milošević, jak i Franjo Tudjman czy Milan Kučan poprzez rozpad Jugosławii zamierzali uzyskać jak najwięcej korzyści dla własnych republik. Należy przypomnieć, iż większość ówczesnych polityków dorastała już w socjalistycznej Jugosławii (wyjątek stanowił Franjo Tudjman, ur. 1922 r.). Cała ich kariera polityczna, w przeciwieństwie do starszych polityków, związana była z lokalnymi strukturami partyjnymi i interesami republikańskimi. Z punktu widzenia Serbii i Miloševicia, a więc podkreślanego wcześniej stanowiska konieczności odbudowy serbskiej pozycji, była ona możliwa jedynie na drodze konfrontacji z innymi republikami.

Należy też się zastanowić, kiedy doszło do realnego „zerwania więzów na płaszczyźnie jugosłowiańskiej”. Milošević pełnię władzy w Serbii przejął na jesieni 1987 roku. Symptomy poważnego i, co najważniejsze, narastającego kryzysu były już bardzo widoczne. Co więcej, kryzysy narodowościowe, choć w nieporównanie mniejszym stopniu, pojawiały się w Jugosławii jeszcze za życia Tity i tuż po nim. W warunkach kryzysu gospodarczego początku lat osiemdziesiątych postępowała niekontrolowana decentralizacja - polityka gospodarcza na szczeblu federacji nie była koordynowana (w zasadzie nie istniała), pozostawiając $\mathrm{w}$ domenie republik walkę z załamaniem gospodarczym. Pojawiły się głosy krytyki ustroju federacyjnego, głównie w Słowenii i Serbii. Paraliż decyzyjny jeszcze bardziej komplikował i pogłębiał różnice ${ }^{22}$.

Na problemy wewnętrzne Jugosławii nałożyła się niekorzystna sytuacja międzynarodowa. Konflikt w Zatoce Perskiej zaangażował Stany Zjednoczone, które nie próbowały wywrzeć presji ani na Miloševicia, ani na dążące do secesji republiki. Podobne stanowisko zajmowały Francja i Wielka Brytania, które oficjalnie popierały jedność państwa jugosłowiańskiego, jednakże pozostawały bierne wobec wydarzeń w tym kraju. Polityka taka dawała zielone światło wszystkim stronom konfliktu. Nawet administracja Busha świadoma była tego, że rozpad Jugosławii będzie równoznaczny z wybuchem krwawej wojny domowej ${ }^{23}$. Milošević przystąpił do niej jako najsilniejsza ze stron - wspierając serbskie ruchy separatystyczne w Krajinie i Republice Serbskiej w Bośni, realizował koncepcję wielkoserbską ${ }^{24}$. Co ciekawe, mimo szalejącej krwawej wojny poplecznicy wodza na wiecach i okolicznościo-

${ }^{22}$ Szerzej o narastaniu kryzysu w Jugosławii od początku lat osiemdziesiątych por. M. J. Zacharias, Komunizm, federacja, nacjonalizmy, s. 399 i n.

Tamże, s. 542 i n.

M. Tanty, Bałkany w XX wieku. Dzieje polityczne, Warszawa 2003, s. 348-351. 
wych uroczystościach nie wahali się zapewniać świata o „narodzie serbskim miłującym pokój i patrzącym w przyszłość" ${ }^{25}$.

\section{Zachód a Milošević}

Polityka państw Zachodu wobec Jugosławii była wyjątkowo niespójna I niekonsekwentna. U progu swej drogi do pełni władzy Milošević wzbudzał sympatię w kręgach zachodnich dyplomatów. Co prawda był uważany za aparatczyka komunistycznego, jednakże jego liberalne - jak na ówczesne warunki - poglądy gospodarcze oraz krytyka nacjonalizmu dawały nadzieję na stopniową transformację Jugosławii najpierw na polu gospodarczym, a potem - być może - politycznym. Nawet gdy opinia publiczna zaczęła widzieć w nim „rzeźnika Bałkanów” ${ }^{\text {,2 }}$, administracja Clintona chwaliła go za rozsądek polityczny (przyjęcie porozumienia z Dayton), ogłaszając Miloševicia "gwarantem pokoju na Bałkanach" ${ }^{27}$. Jak podkreślał z nutą ironii emerytowany profesor historii z uniwersytetu w Kalifornii Raymond Kent podczas wizyty w USA Miloševicia, nikt nie oskarżał o zbrodnie, nie próbował aresztować. Nikt nawet nie próbował zadawać pytań o przebieg wojny w Bośni ${ }^{28}$ czy wcześniejsze odrzucenie planów pokojowych (Milošević raczej nie miał wyjścia - ustalenia Konferencji Pokojowej KBWE z 18 października 1991 roku zakładały uznanie niepodległości wszystkich republik tworzących Jugosławię).

Winą za eskalację kolejnego konfliktu serbsko-albańskiego w Kosowie (problem ten nie został poruszony na konferencji w Dayton, co było gestem w stronę Miloševicia) obarczono wyłącznie Serbię. Tym razem jednak Zachód, a w szczególności Stany Zjednoczone, zdecydował się rozwiązać problem przy użyciu siły ${ }^{29}$. Dowództwo NATO zdecydowało o rozpoczęciu bombardowania Jugosławii, rozpoczynając kolejny etap tragedii na Bałkanach. Głównym motywem podjęcia interwencji było zapobieżenie klęsce humani-

25 Słowa te wypowiedział 29 czerwca 1995 roku Dragan Tomić, ówczesny przewodniczący Skupsztyny, od 1997 roku pełnił funkcję prezydenta Serbii. Cyt. za: I. Čolović, Polityka symboli. Eseje o antropologii politycznej, Kraków 2001, s. 115.

${ }^{26}$ Odpowiedzialność Miloševicia za zbrodnie mu przypisywane wciąż jest problematyczna.

${ }^{27}$ A. Koseski, W bałkańskim tyglu, Pułtusk 2002, s. 176-177. Opinii tej nie podzielało kilka krajów europejskich uchodzących za największych krytyków polityki Miloševicia i orędowników rozbicia Jugosławii. Wśród nich wymienić należy Austrię - jej minister spraw zagranicznych Alois Mock opracował nawet plan ataku na Serbię. Kolejnym państwem były Niemcy, których udaną inicjatywą dyplomatyczną była zapowiedź uznania secesjonistycznych republik przez WE, co było jedną z przyczyn eskalacji konfliktu. Por. M. Waldenberg, Rozbicie Jugosławii: od separacji Stowenii do wojny kosowskiej, Warszawa 2003, s. 87-100. R. K. Kent, Milošević, The Serbs and The West, http://romnews.com/community/ modules.php?op=modload\&name=News\&file=article\&sid=397 [dostęp: 12.03.2010].

29 Szerzej o konflikcie kosowskim zob. D. Gibas-Krzak, Serbsko-albański konflikt o Kosowo w XX wieku. Uwarunkowania - przebieg - konsekwencje, Toruń 2009, s. 167-204. 
tarnej w Kosowie. Podkreślano konieczność „przeciwstawienia się barbarzyńskim praktykom”, „niesienia wartości zachodnich na Bałkany”, ,walki z dyktatorami" ${ }^{30}$. Naloty, w założeniu Madeleine Albright mające trwać maksymalnie kilka dni, trwały przez dni 78, przy czym rozpoczęto niszczenie serbskiej infrastruktury cywilnej ${ }^{31}$. „Wojna totalna”, jak niektórzy nazwali ten konflikt, miała na celu „złamanie woli narodu serbskiego, ${ }^{32}$. Paradoksalnie Milošević stanowisko utrzymał, co więcej - zyskał sławę jako ten, który stawił czoło zachodniemu imperializmowi. Interwencja w Jugosławii nie zmieniła zasadniczo sytuacji w regionie, może poza faktem wprowadzenia wojsk międzynarodowych do Kosowa oraz zrujnowania gospodarczego Serbii.

\section{Konkluzje}

Rządy Miloševicia doprowadziły do jednego z największych kryzysów w historii Serbii. Porażka w trzech kampaniach wojennych spowodowała utratę terytoriów i wpływów. Na kraj zostały nałożone sankcje ${ }^{33}$. Mimo tak dotkliwych porażek Miloševiciowi udało się utrzymać relatywnie wysokie poparcie społeczne. W wyborach do parlamentu Serbii oraz parlamentu związkowego w 2000 roku (w rok po zakończeniu bombardowań) jego partia (Socjalistyczna Partia Serbii - SPS) zdobyła 13,5\% mandatów, a do federalnego aż 31,9\%. Demokratyczna Opozycja Serbii, najsilniejsza koalicja opozycyjna, odpowiednio $63,9 \%$ i 42,0\%. Wyniku tego nie udało się powtórzyć w 2003 roku, ale SPS uzyskała (aż?) 9,5\% głosów, co - mając na uwadze rozpoczynający się proces wodza w Hadze - należy uznać za spory sukces. W tym samym czasie poparcie dla opozycji stopniało o połowę, do $36,5 \%$ głosów ${ }^{34}$. Milošević przetrwał czasy, kiedy inflacja w Jugosławii osiągała astronomiczny poziom $313000000,00 \%$, a bank centralny emitował banknoty o nominale

\footnotetext{
N. Chomsky, The New Military Humanism. Lessons from Kosovo, London 1999, s. 3-5.

Nie chodzi tu o omyłkowe zbombardowanie szpitali czy ambasady chińskiej, które, choć naganne, można wytłumaczyć. Mam na myśli celowe i metodyczne niszczenie infrastruktury - elektrowni, dróg, mostów itp. Szerzej o koncepcjach i przebiegu interwencji NATO w Jugosławii patrz: M. Marszałek, Sojusznicza operacja „Allied Force”. Przebieg-ocena-wnioski, Torun 2009, s. 12-20, 67-115.

R. K. Kent, Milošević...

33 Documents. The United Nations and former Yugoslavia: selected resolutions, http:// ijrl.oxfordjournals.org/cgi/pdf_extract/4/3/393, [dostęp: 12.03.2010]. Mihailo Marković, serbski filozof, tak opisywał sytuację w Serbii w 1993 roku: „Świat uważający się za chrześcijański [...] skazał cały nasz naród na zbiorowe więzienie. A jednak nie mógł nam odebrać przyrody i ducha. Słońce wciąż nas grzeje, deszcze wciąż nawilżają nasze pola. Z głębi ziemi wciąż wyrastają nasze zboża i trawy, wciąż wydobywamy z niej rudy. Tego nie mogli nam zabrać" cyt. za: I Čolović, Polityka symboli..., s. 16-17.

34 J. Wojnicki, Przeobrażenia ustrojowe państw postjugosłowiańskich, 1990 - 2003, Oficyna, Pułtusk 2003, s. 214-218.
} 
50000000000 (słownie: pięćdziesiąt miliardów) dinarów, choć w praktyce w użyciu była marka niemiecka ${ }^{35}$. SPS natomiast przetrwała swojego wodza. Nacjonalistyczne hasła, które wyniosły do władzy Miloševicia, przejęte zostały przez Serbską Partię Radykalną (SPR), która stała się jednym z najistotniejszych aktorów na serbskiej scenie politycznej.

Po obaleniu dyktatora sytuacja gospodarcza w Serbii powoli zaczęła się stabilizować, jednak nie jest to proces łatwy, szczególnie biorąc pod uwagę skomplikowaną sytuację międzynarodową ${ }^{36}$. Wydaje się jednak, iż Serbia nie ma alternatywy poza rozpoczęciem procesu integracji. Europejskie fundusze pomocowe oraz zmiana prawa wewnętrznego mogą się okazać pozytywnym bodźcem do dokończenia procesu odbudowy Serbii oraz stworzenia ładu zapewniającego pokój na Bałkanach.

Wraz z odejściem Miloševicia z serbskich domów odeszły wizje zbrodni wojennych, nalotów, rozprzestrzeniającej się biedy. Oceniając rządy tego polityka negatywnie, należy zaznaczyć, iż miał on znaczne poparcie społeczne. Po dekadzie od jego obalenia i czterech latach od śmierci niemal w każdych serbskich wyborach powracają demony przeszłości w postaci nacjonalistycznych haseł, kiedyś wykorzystywanych przez Miloševicia.

P A W E E W A W R S Z U K

35 S. Hanke, Hyperinflation: Mugabe vs Milošević, „GlobeAsia” 2008, August, s. 187-188, http://www.freemarketfoundation.com/Hanke\%5CHyperinflation--

Mugabe\%20versus\%20Milosevic.pdf, [dostęp: 17.03.2010].

Z powodu uznania niepodległości Kosowa przez większość krajów Unii Europejskiej, doszło do ochłodzenia stosunków z Brukselą. Po utworzeniu proeuropejskiego rządu Cvetkovicia doszło do odmrożenia umowy o współpracy gospodarczej w konsekwencji zniesienia wiz dla Serbów, jednakże wzajemna współpraca nadal pozostaje na niezadowalającym poziomie. Od dwóch lat trwa normalizowanie stosunków dwustronnych z USA (po zerwaniu stosunków dyplomatycznych w wyniku deklaracji niepodległości Kosowa) oraz innymi państwami uznającymi Kosowo. 


\section{Abstract}

Slobodan Milošević's brilliant political career began from the speech delivered on Kosovo Field in April 1987. The sentence "nobody has the right to beat you" captivated Serbian crowds, complaining about discrimination from Kosovars. His theses about the necessity of reconstruction of the historical position of Serbia, the restoration of autonomic districts (Vojvodina and Kosovo) for the fatherland, found an acknowledgement in society. Taking an advantage of the situation, he conducted the "antibureaucracy revolution", which enabled him to gain power in the Communist Party.

Milešević being only a messenger of his nation, executing his infallible will. Therefore the whole fame fell to the nation. On the other hand, the commander did not hold any responsibilities for defeats. The commander received support from a part of artistic environments and the Orthodox Church as well. The culture was the essential aspect of kindling the Serbian nationalism as well as the necessity to defend the Serbian language. According to many poets, Serbian culture was (is?) not limited to state borders, even to terrains where Serbian minority lived, but it was connected with "spiritual space", which was even where there had been no Serbs for decades (centuries). Through years Milošević was altering his rhetoric - he started with critic of nationalism, but in the end he became its propagator.

There is no categorical answer to the question if Milošević was guilty of the break-up of Yugoslavia? It is doubtless that nationalisms among nations of former Yugoslavia caused the explosion of the bloody civil war. However, it might have been assumed that the economic and political situation created circumstances for radical moods to grow among nations of this state. Also the geopolitical situation changed fundamentally in 1991. Middle East conflict became a priority of the USA foreign policy, France and Great Britain weren't involved themselves in saving Yugoslavia. In this circumstances, the war had already decided about the borders of the indenpendent republics.

Over a decade of Slobodan Milošević's rules brought Serbia to huge economic and political crisis. De facto, this country lost its importance in the region, as well as its territory (Kosovo). Many Serbs live outside Serbian boarders in Croatia, Bosnia and Kosovo as well. NATO raids ruined the infrastructure of the country, UN embargo ruined economy. In the years 1992 - 1994 inflation reached the world record of 313 million \% (!). Milošević, overthrown in 2001, was passed on to the Hague War Crimes Tribunal, being accused of the heaviest crimes against mankind. The Court did not manage to judge him - he died for heart attack in a prison cell in 2006. 